\title{
PERSEPSI SISWA SEKOLAH MENENGAH PERTAMA SANTO MARKUS 1 KRAMATJATI TERHADAP ALAT PERAGA SEDERHANA TEROPONG BINTANG PADA MATERI ALAT OPTIK
}

\author{
Taat Guswantoro*1), Faradiba ${ }^{1)}$, Manogari Sianturi ${ }^{2)}$, Thobias Diong Kosnan ${ }^{1)}$. \\ taat.guswantoro@uki.ac.id \\ ${ }^{1)}$ Program Studi Pendidikan Fisika ${ }^{2)}$ Fakultas Kedokteran Universitas Kristen Indonesia
}

\begin{abstract}
Physics learning in junior high school is not only emphasizing mastery of material, concepts or principles but is a very good process in discovering new phenomena so that students can bring real situations or conditions close to everyday life that can be observed and proven directly by students. The right approach is a demonstration method for studying physical phenomena with the aim of providing understanding to students to recognize, understand the material of physics and science, so that information obtained from various media can be useful. The demonstration method instills confidence in students and is a natural or natural way according to the development process of students to learn to understand the lesson. This research was conducted at SMP Santo Markus I in the even semester of the 2017/2018 academic year by demonstrating the making and use of simple star binocular props to 31 students of 9th grade. After the demonstration a questionnaire was given to students to find out the students' responses. From this research, it was found that students liked physics subjects with a response of $77 \%$, liked and understood teaching aids which were demonstrated with a response of $87 \%$, liked the demonstration method demonstrating teaching aids with a response of $88 \%$, better understanding and understanding physics lessons using teaching aids with a response of $89 \%$, having motivation to develop simple teaching aids was $74 \%$.
\end{abstract}

Keywords: Binoculars, Demonstrations, Props

\begin{abstract}
ABSTRAK
Pembelajaran fisika di sekolah menengah pertama tidak hanya sekedar menekankan pada penguasaan materi, konsep atau prinsip tetapi merupakan suatu proses yang sangat baik dalam penemuan fenomena baru sehingga dapat membawa peserta didik dalam situasi atau kondisi nyata dekat dengan kehidupan sehari-hari yang dapat diamati dan dibuktikan secara langsung oleh peserta didik. Pendekatan yang tepat adalah metode demonstrasi untuk mempelajari fenomena fisika dengan tujuan memberikan pemahaman kepada peserta didik untuk mengenal, memahami materi fisika dan sains, sehingga informasi yang diperoleh dari berbagai media dapat bermanfaat. Metode demonstrasi menanamkan keyakinan pada peserta didik serta merupakan cara yang wajar atau alamiah sesuai proses perkembangan peserta didik untuk belajar memahami pelajaran. Penelitian ini dilakukan di SMP Santo Markus I pada semester genap tahun ajaran 2017/2018 dengan melakukan demonstrasi pembuatan dan penggunaan alat peraga teropong bintang sederhana kepada 31 siswa kelas 9. Setelah melakukan demonstrasi diberikan kuisioner kepada para siswa untuk mengetahui respon siswa. Dari penelitian ini diperoleh siswa menyukai mata pelajaran fisika dengan respon sebesar $77 \%$, menyukai dan
\end{abstract}


memahami alat peraga yang didemonstrasikan dengan respon sebesar $87 \%$, menyukai cara demontrator memperagakan alat peraga dengan respon sebesar $88 \%$, lebih mengerti dan memahami pelajaran fisika dengan menggunakan alat peraga dengan respon sebesar $89 \%$, memiliki motivasi untuk mengembangkan alat peraga sederhana sebesar $74 \%$.

Kata kunci: Teropong Bintang, Demonstrasi, Alat peraga

\section{PENDAHULUAN}

Banyak siswa usia sekolah memiliki anggapan bahwa pelajaran IPA itu sulit, khususnya pada ilmu Fisika. Azzizah (2015) mengungkapkan kesulitan yang dialami para siswa tersebut utamanya terletak pada pemahaman konsep, yang kedua adalah adanya kesulitan memahami persamaan. Dengan adanya kesulitan ini sehingga membuat siswa kurang meminati pelajaran IPA, sehingga seorang guru harus menggunakan cara-cara kreatif untuk lebih dapat membuat siswa menjadi paham, secara otomatis juga akan dapat mendongkrak minat belajar siswa. Salah satu cara meningkatakan pemahaman siswa adalah dengan menggunakan alat peraga sebagai media pembelajaran. Berdasarkan penelitian Swasono dkk (2013), dengan penggunaan alat peraga dalam proses belajar mengajar dapat memberikan pengalaman nyata kepada siswa, mengilustrasikan informasi sehingga keterampilan siswa dapat meningkat dan minat belajar siswa juga semakin besar dan berakibat dapat mengurangi rasa malas siswa.

Berdasarkan penelitian Apriliza (2015), pemanfaatan alat peraga berupa bandul dan statif mampu meningkatkan hasil belajar siswa sebesar $33,33 \%$ pada siklus I dan $79,16 \%$ pada siklus 2. Selain meningkatkan hasil belajar, penggunaan alat peraga juga dapat meningkatkan minat belajar siswa sebesar $16,66 \%$ pada siklus 1 dan $54,16 \%$ pada siklus 2 . Senada dengan hal tersebut, Setyowati dkk (2016) melaporkan bahwa dengan menggunakan alat peraga meningkatkan keaktifan siswa dalam materi peluang dari rata-rata 60,0 menjadi 85,4 . Selain keaktifan siswa meningkat, penggunaan alat peraga juga dapat meningkatkan tingkat ketuntasan siswa dari $57,15 \%$ menjadi $94,29 \%$.

Berdasarkan hasil observasi di SMP Santo Markus I Kramatjati, Jakarta Timur diketahui fakta bahwa dalam proses pembelajaran di kelas, guru masih menggunakan metode pembelajaran yang bersifat konvensional atau ekspositori di mana pembelajaran masih sangat biasa dan belum ada inovasi pembelajaran khususnya penggunaan metode demonstrasi alat peraga sederhana sehingga peserta didik kurang bersemangat dalam mengikuti proses pembelajaran terutama mata pelajaran fisika. Sumber pengetahuan hanya didapat dari guru dan buku paket sehingga peserta didik kurang berperan aktif dalam proses pembelajaran maka kemampuan peserta didik tidak berkembang secara optimal, serta pemahaman peserta didik pada pelajaran fisika secara umum masih relatif rendah. 
Berdasarkan fakta-fakta di atas maka dianggap perlu menerapkan sebuah demonstrasi tentang pembuatan dan penggunaan alat peraga sederhana kepada siswa SMP Santo Markus I, dengan tujuan para siswa mudah membuat alat peraga tersebut serta menunjang dalam pembelajaran di kelasnya. Alat yang peraga yang dimaksudkan adalah teropong bintang sederhana yang menunjang dalam materi alat optik.

\section{METODE PENELITIAN}

Penelitian ini dilaksanakan pada bulan Agustus 2018, yaitu pada semester genap tahun ajaran 2018/2019 di SMP Santo Markus I Kramatjati. Penelitian ini dilakukan pada 31 siswa kelas 9. Pada penelitian ini dilakukan demonstrasi pembuatan dan penggunaan teropong bintang sederhana, kemudian setelah selesai demontrasi, siswa dipersilakan untuk mencoba menggunakan alat peraga.

Pelatihan dibagi menjadi dalam 3 tahapan, tahapan pertama adalah penjelasan materi, tahap kedua adalah demonstrasi pembuatan alat peraga serta pemakaian alat peraga dan tahap ketiga adalah pengisian kuesioner respon dari siswa. Pada tahap pertama, peneliti menjelaskan materi tentang teropong bintang, bagian-bagian utama pada teropong bintang, panjang teropong bintang, sifat bayangan pada teropong bintang serta fungsi teropong bintang.

Tahap kedua, peneliti mendemonstrasikan cara pembuatan teropong bintang sederhana, dengan menggunakan pipa dan dua buah lensa yang berbeda jarak fokus nya. Lensa yang memiliki jarak fokus lebih besar akan digunakan sebagai lensa obyektif sedangkan lensa lainnya sebagai lensa okuler, ukuran diameter pipa yang digunakan diusahakan sama dengan ukuran diameter lensa. Setelah selesai merangkai teropong bintang sederhana, peneliti kemudian mendemonstrasikan cara penggunaan teropong bintang dan meminta masing-masing siswa mencoba teropong bintang tersebut untuk melihat benda yang jauh letaknya.

Tahapan ketiga dari penelitian ini, peneliti memberikan kuesioner kepada siswa untuk mengetahui respon dari siswa. Kuesioner yang diberikan adalah dengan skala Likert 1 - 5 dan pengolahan data untuk mengetahui persentase respon siswa digunakan persamaan :

$$
X=\frac{r}{N} \times 100 \%
$$

dengan $X$ adalah persentase respon, $r$ total skor yang diperoleh dan $N$ adalah skor maksimum. Kategori respon ditunjukkan pada tabel 1. 
Tabel 1. Kategori Respon Siswa

\begin{tabular}{lll}
\hline No & Persentase & Kategori Respon \\
\hline 1 & $80,1 \%-100 \%$ & Sangat Baik \\
2 & $60,1 \%-80,0 \%$ & Baik \\
3 & $40,1 \%-60,0 \%$ & Netral \\
4 & $20,1 \%-40,0 \%$ & Tidak Baik \\
5 & $00,0 \%-20,0 \%$ & Sangat Tidak Baik \\
\hline
\end{tabular}

\section{HASIL DAN PEMBAHASAN}

\section{Persiapan Penelitian}

Penelitian ini menggunakan alat peraga berupa teropong bintang sederhana, yang dibuat dengan dua buah lensa cembung yang memiliki panjang fokus 15 dan $50 \mathrm{~cm}$. Agar diperoleh perbesaran yang benar untuk teropong bintang, maka lensa yang panjang fokusnya $50 \mathrm{~cm}$ digunakan sebagai lensa objektif, sedang yang panjang fokusnya $15 \mathrm{~cm}$ digunakan sebagai lensa okuler. Dengan konfigurasi lensa seperti tersebut, maka diharapkan teropong bintang yang dihasilkan akan memiliki perbesaran sebesar 3,33 kali. Gambar 1 menunjukkan alat-alat yang digunakan untuk membuat teropong bintang sederhana.

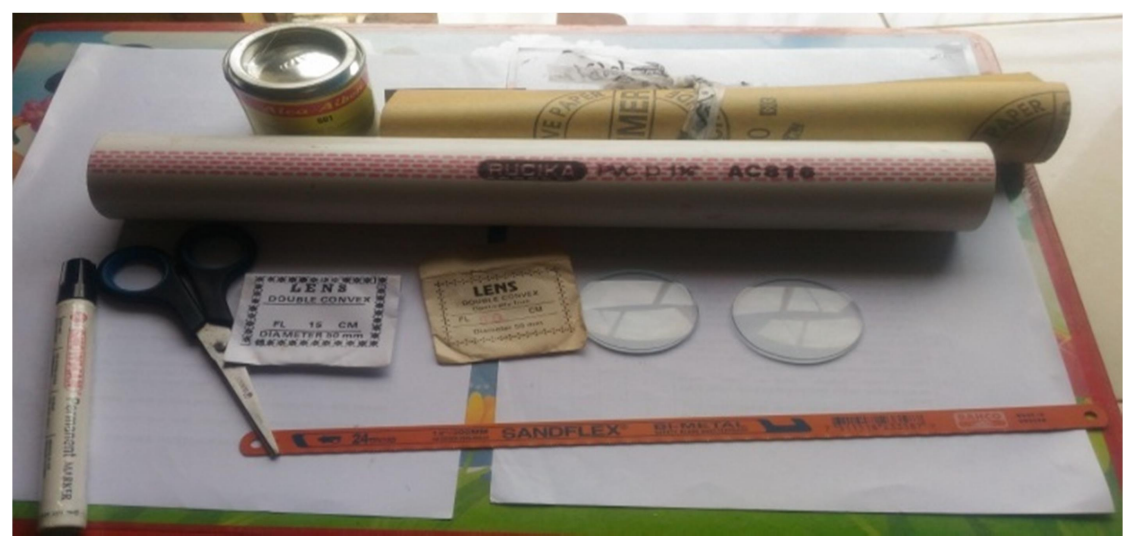

Gambar 1. Alat-alat untuk membuat teropong bintang sederhana.

Batang teropong dibuat dengan menggunakan pipa PVC dengan diameter 2 Inch dan panjangnya $65 \mathrm{~cm}$. Panjang pipa ini ditentukan dengan persamaan yang berlaku pada teropong bintang, yang mana panjang teropong adalah penjumlahan dari jarak fokus lensa objektif dan lensa okuler. Pipa dipotong dengan menggunakan gergaji, kemudian diampelas untuk menghaluskan bagian kasar karena pemotongan. Untuk merangkai sebuah teropong 
bintang maka setiap lensa dilekatkan pada ujung-ujung pipa dengan menggunakan Lem. Gambar 2 menunjukkan hasil teropong bintang yang dibuat.

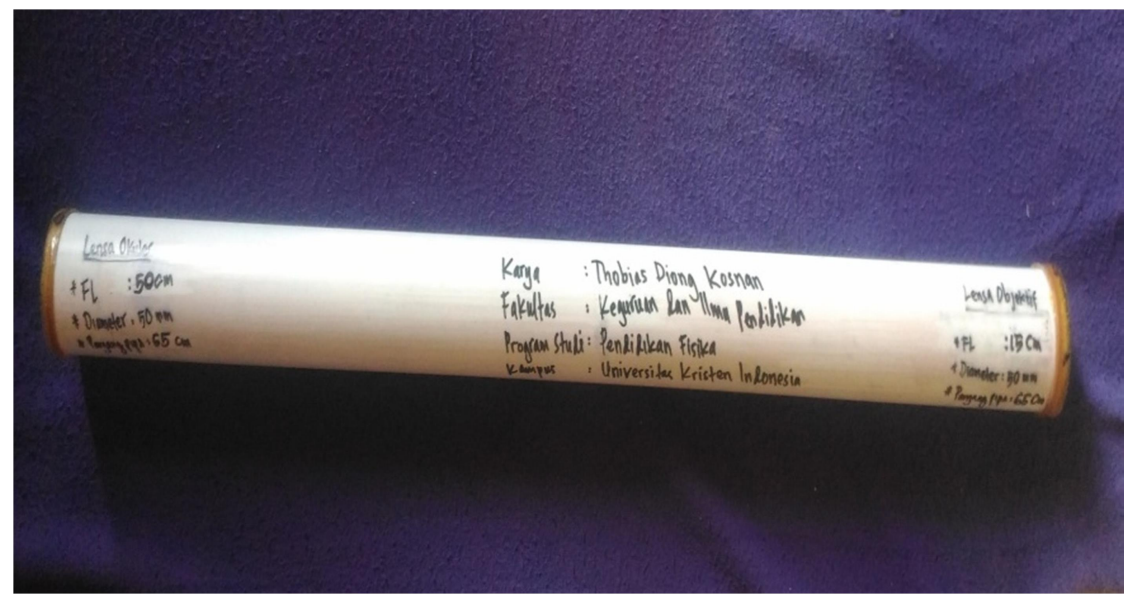

Gambar 2. Alat peraga teropong bintang sederhana

Cara menggunakan teropong bintang adalah dengan cara mengarahkan lensa obyektif pada sebuah benda yang jauh, sedangkan mata pengguna melihat pada lensa okuler. Karena perbesaran yang dihasilkan oleh teropong, maka terkesan benda yang jauh tersebut akan terlihat lebih dekat. Benda yang teramati dengan teropong bintang akan terlihat terbalik, karena ini sesuai dengan sifat bayangan yang dihasilkan oleh teropong bintang yaitu Maya, terbalik dan diperbesar. Ketika terbalik penggunaannya maka akan diperoleh bayangan yang justru diperkecil, sehingga benda terkesan lebih jauh. Gambar 3 menunjukkan perbedaan penggunaan teropong bintang yang benar dan terbalik.

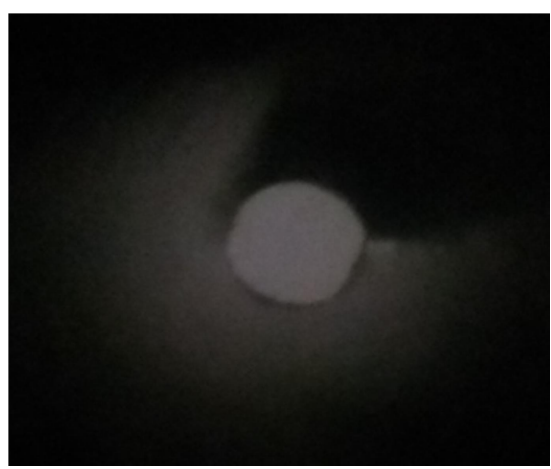

( a )

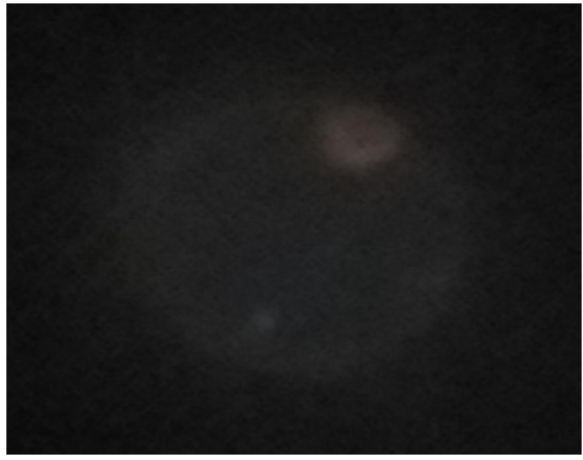

( b )

Gambar 3 (a) Penggunaan teropong bintang yang benar, menghasilkan bayangan diperbesar. (b) Penggunaan teropong bintang terbalik menghasilkan bayangan yang diperkecil. 


\section{Pelaksanaan Penelitian}

Sebelum dilaksanakan demontrasi kepada para siswa, sebelumnya peneliti telah membuat 1 buah teropong bintang yang sudah jadi, dan menyiapkan bahan-bahan yang akan dibuat untuk membuat 1 buah teropong bintang lagi, seperti yang ada di gambar 1 . Di depan kelas, sebelum demonstrasi pembuatan teropong bintang, peneliti menjelaskan tentang alat optik teropong bintang. Tahap selanjutnya, peneliti mendemonstrasikan pembuatan teropong bintang hingga terbentuk sebuah teropong bintang sederhana, sehingga terdapat dua buah teropong bintang yang dapat digunakan.

Untuk lebih memahami mengenai teropong bintang, setiap siswa dipersilahkan untuk mencoba penggunaan teropong bintang, dengan meneropong benda yang letaknya jauh. Para siswa memperoleh bahwa benda terlihat semakin dekat tetapi posisinya terbalik. Peneliti menjelaskan bahwa hal tersebut sesuai dengan teori bahwa sifat bayangan yang dihasilkan teropong bintang adalah maya, diperbesar dan terbalik. Setelah masing-masing siswa mencoba menggunakan teropong bintang, maka selanjutnya diberikan kuisioner untuk mengetahui respon siswa tentang penelitian yang sedang dilakukan. Pernyataan-pernyataan dalam kuisioner adalah untuk mengetahui respon para siswa terhadap mata pelajaran fisika, Alat peraga sederhana, demonstrator atau peneliti, manfaat kegiatan demontrasi dan pengaruh kegiatan demonstrasi alat peraga.

\section{Persepsi Peserta Didik Terhadap Pelajaran Fisika}

Persepsi peserta didik terhadap pelajaran Fisika diperoleh dari pernyataan-pernyataan yang ditampilkan dalam tabel 2. Dapat terlihat bahwa rata-rata para siswa menyukai pelajaran fisika dengan respon sebesar $77 \%$. Menurut para siswa mereka menyukai pelajaran fisika karena membantu dalam kehidupan sehari-hari dengan respon $77 \%$, respon sebesar $70 \%$ menyatakan bahwa pelajaran fisika itu asyik dan menyenangkan, Pelajaran fisika juga dinilai dekat dengan kehidupan sehari-hari dengan respon $75 \%$, respon yang terbesar adalah mereka menyukai pelajaran fisika karena pada saat belajar fisika dapat dilakukan dengan bantuan alat peraga dengan respon sebesar $87 \%$.

Tabel 2. Persepsi Peserta Didik Terhadap Pelajaran Fisika

\begin{tabular}{llll}
\hline No & Pernyataan & Nilai & Kategori \\
\hline 1 & Saya senang belajar fisika, karena pelajaran fisika membantu & $77 \%$ & Baik \\
& saya dalam kehidupan sehari-hari.
\end{tabular}




\begin{tabular}{|c|c|c|c|}
\hline 2 & Saya suka fisika, karena fisika itu asyik dan menyenangkan. & $70 \%$ & Baik \\
\hline 3 & $\begin{array}{l}\text { Saya suka fisika, karena fisika itu dekat dengan kehidupan } \\
\text { manusia. }\end{array}$ & $75 \%$ & Baik \\
\hline & Saya senang belajar fisika dengan berbantuan alat peraga. & $87 \%$ & Sangat Baik \\
\hline & Rata-rata & $77 \%$ & Baik \\
\hline
\end{tabular}

Dengan hasil ini, maka dapat diperoleh bahwa para siswa menyukai pelajaran fisika karena asyik dan menyenangkan, dekat dan membantu dalam kehidupan sehari-hari serta dalam mempelajarinya dapat dibantu dengan menggunakan alat peraga. Dari pernyataan nomor 10 diperoleh bahwa salah satu faktor yang mempengaruhi minat belajar para siswa adalah dengan adanya alat peraga, hal ini sesuai dengan pernyataan bahwa penggunaan alat peraga dapat meningkatkan minat belajar para siswa.

\section{Persepsi Siswa Terhadap Alat Peraga Sederhana Teropong Bintang}

Persepsi peserta didik terhadap alat peraga sederhana teropong bintang diperoleh dari pernyataan-pernyataan yang ditampilkan dalam tabel 3. Dapat terlihat bahwa rata-rata para siswa sangat menyukai alat peraga sederhana teropong bintang dengan respon sebesar $87 \%$. Menurut para siswa mereka menyukai alat peraga teropong bintang ini karena alat peraga tersebut menarik dan mudah dipahami dengan respon sebesar $88 \%$, selain itu respon sebesar $86 \%$ menyatakan bahwa alat peraga sesuai dengan teori senada dengan itu $81 \%$ menyatakan sesuai dengan teori optik, sebanyak $88 \%$ merespon bahwa alat peraga tersebut bermanfaat, sebanyak $89 \%$ meyatakan alat peraga tersebut memberikan pengetahuan baru senada dengan respon ini sebanyak $90 \%$ para siswa berpendapat bahwa pengetahuan mereka bertambah dengan adanya alat peraga tersebut.

Tabel 3. Persepsi Siswa Terhadap Alat Peraga Sederhana Teropong Bintang

\begin{tabular}{llrl}
\hline No & Pernyataan & Nilai & Kategori \\
\hline 4 & Alat peraga yang didemonstrasikan itu menarik dan & $88 \%$ & Sangat Baik \\
& memberikan gambaran yang baik serta mudah dipahami. & & \\
5 & $\begin{array}{l}\text { Alat peraga sederhana yang didemonstrasikan itu mudah dan } \\
\text { sesuai teorinya. }\end{array}$ & $86 \%$ & Sangat Baik \\
6 & $\begin{array}{l}\text { Alat peraga yang didemonstrasikan itu sederhana, namun } \\
\text { banyak manfaatnya. }\end{array}$ & $88 \%$ & Sangat Baik \\
7 & Alat peraga mudah dipahami dan memberikan banyak & $89 \%$ & Sangat Baik \\
\hline
\end{tabular}


pengetahuan baru.

8 Alat peraganya sesuai dengan teori optik yang telah dipelajari. $81 \% \quad$ Sangat Baik

9 Dengan adanya alat peraga sederhana ini menambah $\quad 90 \%$ Sangat Baik pengetahuan saya.

Rata-rata $87 \%$ Sangat Baik

Dengan hasil ini, dapat disimpulkan bahwa para siswa sangat terbantu dengan adanya alat peraga ini karena selain menarik, menurut mereka juga dengan menggunakan alat peraga dapat memberikan pengetahuan baru, bahkan menambah pengetahuan mereka, karena sesuai dengan materi yang diajarkan yaitu tentang optik. Hal ini membuktikan bahwa alat peraga mampu memberikan pengalaman bagi siswa tentang sesuatu yang diajarkan, mempraktikan dan mengamati secara langsung sehingga dapat menambah pengetahuan mereka.

\section{Persepsi Siswa Terhadap Demonstrator}

Persepsi peserta didik terhadap demonstator diperoleh dari pernyataan-pernyataan yang ditampilkan dalam tabel 4. Dapat terlihat bahwa rata-rata para siswa berpendapat bahwa demonstator dapat melaksanakan demonstrasi dengan sangat baik, yaitu dengan rata-rata respon sebesar $88 \%$. Menurut para siswa, demonstrator selama melaksanakan demonstrasi dan pengajaran sangat ramah terhadap siswa, yaitu dengan respon sebesar $92 \%$. Selain keramahan demonstrator, faktor lain yang dinilai adalah mengenai performa dari demonstrator, dari segi kemampuan penjelasan mendapatkan respon yang sangat baik yaitu sebesar 92\%, demonstrator dinilai sangat baik dalam ketepatan meyampaikan materi, dengan respon sebesar $86 \%$, ketepatan dalam menjawab pertanyaan direspon sebesar $85 \%$. Demonstrator dinilai sangat piawai dalam memberikan petunjuk dengan respon sebesar $90 \%$, serta respon terhadap kemampuan memberikan gambaran umum juga dalam kategori sangat baik yaitu sebesar $91 \%$.

Tabel 4. Persepsi Siswa Terhadap Demonstator

\begin{tabular}{|c|c|c|c|}
\hline No & Pernyataan & Nilai & Kategori \\
\hline 11 & Ramah terhadap siswa selama demonstrasi berlangsung. & $92 \%$ & Sangat Baik \\
\hline 12 & $\begin{array}{l}\text { Kemampuan dan ketepatan demonstrator dalam memberikan } \\
\text { penjelasan mengenai alat peraga sederhana sangat baik. }\end{array}$ & $86 \%$ & Sangat Baik \\
\hline 13 & $\begin{array}{l}\text { Kemampuan dan ketepatan demonstrator dalam menjawab } \\
\text { pertanyaan dari peserta didik. }\end{array}$ & $85 \%$ & Sangat Baik \\
\hline
\end{tabular}




\begin{tabular}{llll}
\hline 14 & $\begin{array}{l}\text { Kemampuan demonstrator dalam memberikan petunjuk } \\
\text { berlangsungnya demonstrasi alat peraga teropong. }\end{array}$ & $90 \%$ & Sangat Baik \\
15 & $\begin{array}{l}\text { Kemampuan demonstrator memberikan gambaran umum } \\
\text { mengenai penggunaan alat peraga teropong. }\end{array}$ & $91 \%$ & Sangat Baik \\
& Rata-rata & $88 \%$ & Sangat Baik \\
\hline
\end{tabular}

Berdasarkan hasil tersebut, dapat disimpulkan bahwa demonstrator dinilai sangat baik oleh para siswa dalam melakukan demonstrasi alat peraga sederhana, hal ini berkaitan dengan hasil-hasil sebelumnya karena pada dasar nya mereka telah menyukai pelajaran fisika, serta alat peraga yang didemonstrasikan menarik, ditambah performa dari demontrator yang baik, sehingga dinilai piawai dalam melaksanakan demonstrasi. Pada point penilaian ini, peneliti menyimpulkan bahwa minat siswa akan semakin meningkat ketika demontrator mampu melaksanakan demonstrasi dengan baik, sehingga siswa antusias dalam mengikuti pelajaran.

\section{Persepsi Siswa Terhadap Manfaat Kegiatan Demonstrasi Alat Peraga Sederhana}

Persepsi peserta didik terhadap manfaat kegiatan demontrasi alat peraga sederhana diperoleh dari pernyataan-pernyataan yang ditampilkan dalam tabel 5. Dapat terlihat bahwa rata-rata para siswa berpendapat bahwa kegiatan demonstrasi alat peraga sederhana ini sangat bermanfaat, dengan rata-rata respon sebesar $89 \%$. Para siswa sangat merasakan manfaat yang positif dari kegiatan tersebut, dengan respon 91\%, para siswa juga berpendapat bahwa kegiatan demonstrasi tersebut memberikan pengalaman yang sangan baik bagi mereka dengan respon sebesar $86 \%$. Manfaat lain yang dirasakan para siswa adalah menambah wawasan dan pengetahuan dalam bidang IPA, dengan respon sebesar $91 \%$, serta menambah wawasan dalam pembuatan alat peraga sederhana khususnya di bidang IPA, dengan respon sebesar $90 \%$.

Tabel 5. Persepsi Siswa Terhadap Manfaat Kegiatan Demonstrasi Alat Peraga

\section{Sederhana}

\begin{tabular}{llll}
\hline No & Pernyataan & Nilai & Kategori \\
\hline 16 & $\begin{array}{l}\text { Demonstrasi alat peraga memberikan banyak manfaat yang } \\
\text { positif. }\end{array}$ & $91 \%$ & Sangat Baik \\
17 & $\begin{array}{l}\text { Demonstrasi alat peraga sederhana memberikan banyak } \\
\text { pengalaman yang sangat baik. }\end{array}$ & $86 \%$ & Sangat Baik \\
& & &
\end{tabular}




\begin{tabular}{llll}
\hline 18 & Kegiatan demonstrasi alat peraga sederhana menambah & $91 \%$ & Sangat Baik \\
& wawasan dan pengetahuan saya dalam pelajaran IPA. & & \\
Kegiatan demonstrasi menambah wawasan saya dalam & $90 \%$ & Sangat Baik \\
membuat alat peraga sederhana pelajaran IPA. & Rata-rata & $89 \%$ & Sangat Baik \\
\hline
\end{tabular}

Berdasarkan hasil pada tabel 5, dapat disimpulkan bahwa para siswa memperoleh banyak manfaat dari kegiatan demonstrasi tersebut, manfaat yang dirasakan para siswa adalah memperoleh wawasan dan pengetahuan baru tentang alat peraga sederhana khususnya pada pelajaran IPA. Hal ini membuktikan bahwa salah satu manfaat penggunaan alat peraga sederhana dapat menambah wawasan dan pengetahuan bagi para siswa.

\section{Persepsi Siswa Terhadap Pengaruh Metode Demonstrasi Alat Peraga Sederhana}

Persepsi siswa terhadap pengaruh metode demontrasi alat peraga sederhana diperoleh dari pernyataan-pernyataan yang ditampilkan dalam tabel 6. Dapat terlihat bahwa rata-rata para siswa berpendapat bahwa kegiatan demonstrasi alat peraga sederhana ini bermanfaat bagi mereka, dengan rata-rata respon sebesar $74 \%$. Para siswa berpendapat bahwa mereka akan lebih paham ketika guru yang mengajar menggunakan metode demonstrasi dengan alat peraga, dengan respon sebesar $88 \%$, mereka juga memiliki keinginan untuk membuat alat peraga sederhana teropong bintang, dengan respon sebesar $81 \%$, para siswa ingin merangkai teropong bumi sebagai kelanjutan dari teropong bintang dengan respon sebesar $78 \%$. Menurut para siswa respon sebesar $68 \%$ mereka melakukan pengamatan bintang dengan menggunakan Handphone, respons sebesar 55\% menyatakan bahwa mereka belajar IPA karena ingin merakit alat peraga.

Tabel 6. Persepsi siswa terhadap pengaruh metode demonstrasi alat peraga sederhana

\begin{tabular}{llll}
\hline No & Pernyataan & Nilai & Kategori \\
\hline 20 & $\begin{array}{l}\text { Saya lebih paham, jika guru mengajar dengan menggunakan } \\
\text { alat peraga sederhana. }\end{array}$ & $88 \%$ & Sangat Baik \\
21 & $\begin{array}{l}\text { Saya belajar IPA karena saya ingin menjadi perakit alat-alat } \\
\text { peraga fisika. }\end{array}$ & $55 \%$ & Netral \\
22 & $\begin{array}{l}\text { Saya suka mengamati bintang dengan kamera handphone } \\
\text { saya, namun permukaan bintang belum nyata. }\end{array}$ & $68 \%$ & Baik \\
\hline
\end{tabular}


23 Saya ingin merangkai teropong bintang dengan alat dan bahan $81 \%$ Sangat Baik yang sederhana.

24 Saya ingin menunjukan kemampuan bahwa saya bisa $\quad 78 \% \quad$ Baik merangkai teropong bumi dan bintang.

Rata-rata $74 \%$ Baik

Berdasarkan hasil pada tabel 6, dapat diketahui bahwa para siswa mendapat pengaruh yang baik dengan metode demonstrasi. Mereka akan merasa lebih paham ketika guru mengajar dengan menggunakan metode demonstrasi menggunakan alat peraga sederhana, para siswa juga tertarik untuk mengembangkan alat peraga, namun menurut mereka juga mereka belajar IPA bukan karena ingin merakit alat peraga. Hal ini membuktikan bahwa dengan menggunakan alat peraga dapat merangsang kreativitas siswa untuk mengembangkan ilmu yang dia peroleh, yang dibuktikan dengan keinginan para siswa untuk merangkai teropong bumi sederhana yang menghasilkan bayangan tegak, sehingga cocok untuk digunakan meneropong benda yang jauh di permukaan bumi.

\section{KESIMPULAN DAN SARAN}

Demonstrasi pembuatan dan penggunaan alat peraga sederhana yang dilakukan kepada siswa kelas 9 SMP Santo Markus 1 Kramatjati dinilai oleh siswa mampu meningkatkan pemahaman dan meningkatkan minat siswa untuk belajar IPA. Alat peraga dinilai dekat dengan kehidupan sehari-hari dan mudah untuk diperagakan ditambah kepiawaian dalam mendemonstrasikan cara pembuatan alat peraga membuat siswa semakin tertarik dengan alat peraga tersebut. Siswa memiliki respon yang baik terhadap mata pelajaran fisika, sangat baik untuk alat peraga, demonstrator dan manfaat alat peraga, respon yang baik juga untuk manfaat dari demonstrasi alat peraga sederhana.

Berdasarkan hasil yang diperoleh, maka peneliti memberikan saran khususnya kepada guru-guru IPA tingkat SMP untuk menggunakan kreativitasnya dalam menciptakan alat-alat peraga sederhana untuk meningkatkan pemahaman dan minat siswa dalam belajar IPA.

\section{ACUAN PUSTAKA}

Apriliza, Nora. (2015). Upaya Meningkatkan Minat dan Hasil Belajar Siswa Melalui Pemanfaatan Alat Peraga Berupa Bandul dan Statif Pada Materi Getaran di Kelas VIII.2 SMP Negeri 3 Pemuludan. Jurnal Inovasi dan Pembelajaran Fisika Vol. 2 No.1 pp $69-76$ 
Azizah, Rismatul., Lia Yuliati dan Eny Latifah. (2015). Kesulitan Pemecahan Masalah Fisika pada Siswa SMA. Jurnal Penelitian Fisika dan Aplikasinya (JPFA) Vol. 5 No. 2 pp 44 50.

Setyowati, Nining., Bambang Eko Susilo dan Masrukan. (2016). Penggunaan Alat Peraga Untuk Meningkatkan Hasil Belajar dan Keaktifan Siswa Pada Materi Peluang. Kreano Vol. 7 No. 1 pp $24-30$.

Swasono, Fajar., Agus Suyatna dan Feriansyah Sesunan. (2013). Pengembangan Alat Konversi Energi Sebagai Alat Peraga Perubahan Eneergi. Jurnal Pembelajaran Fisika Vol. 1 No. 4 pp $99-111$. 